J. Lake Sci. (湖泊科学), 2016, 28(4): 743-754

DOI 10. 18307/2016. 0407

(c) 2016 by Journal of Lake Sciences

\title{
西藏湖泊水体中主要离子分布特征及其对区域气候变化的响应”
}

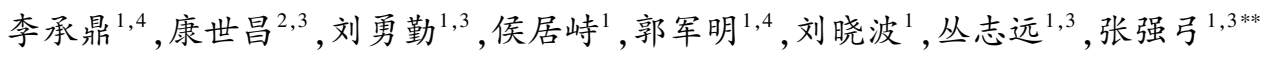
(1: 中国科学院青藏高原环境变化与地表过程重点实验室,北京 100101)

(2: 中国科学院寒区早区环境与工程研究所冰冻圈科学国家重点实验室,兰州 730000)

(3: 中国科学院青藏高原地球科学卓越创新中心, 北京 100101)

(4: 中国科学院大学,北京 100049)

摘 要: 于 2009-2010 年对西藏 34 个湖泊表层水体进行采样和水质参数测量, 测试不同湖泊水体主要离子浓度, 分析 其分布特征和对区域气候变化的响应. 研究表明, 不同湖泊水体的主要离子浓度及其水质参数存在差异, 西藏大部分湖 泊离子浓度高于全国甚至全球湖泊平均水平. 湖泊的水化学类型主要为氯化物型, 少部分是硫酸盐型. 西藏湖泊受强烈 蒸发作用的影响, 水化学类型从东南到西北依次为碳酸盐型-硫酸钠型-硫酸钾型-氯化物型. 对比 $1990 \mathrm{~s}$ 前的研究发现, 大 部分湖泊水体的主要离子浓度较上世纪有所降低, 且部分湖泊水化学类型也发生了变化, 该变化反映了过去几十年来西 藏湖泊水化学对区域气候变化的响应.

关键词: 西藏; 湖泊水体; 主要离子; 分布特征; 响应; 区域气候

\section{Distribution of major ions in waters and their response to regional climatic change in Ti- betan lakes}

LI Chengding ${ }^{1,4}$, KANG Shichang ${ }^{2,3}$, LIU Yongqin ${ }^{1,3}$, HOU Juzhi ${ }^{1}$, GUO Junming ${ }^{1,4}$, LIU Xiaobo ${ }^{1}$, CONG Zhiyuan $^{1,3}$ \& ZHANG Qianggong ${ }^{1,3 * *}$

(1: Key Laboratory of Tibetan Environment Changes and Land Surface Processes, Institute of Tibetan Plateau Research, Chinese Academy of Sciences, Beijing 100101, P.R.China)

(2: State Key Laboratory of Cryospheric Sciences, Cold and Arid Regions Environmental and Engineering Research Institute, Chinese Academy of Sciences, Lanzhou 730000, P.R.China)

(3: Center for Excellence in Tibetan Plateau Earth Science, Chinese Academy of Sciences, Beijing 100101, P.R.China)

(4: University of Chinese Academy of Sciences, Beijing 100049, P.R.China)

Abstract: During 2009-2010, surface water samples from 34 Tibetan lakes were collected and measured for major ions. The distribution pattern of ionic concentrations and its response to regional climatic change were investigated. Results revealed a large range of major ionic concentrations as well as other water parameters for the lakes. Most lakes showed higher ionic concentrations than lakes in other regions of China and even the world. Most of the lakes' water types were found to be $\mathrm{Na}(\mathrm{K})$ - $\mathrm{Cl}$ with a few as Ca $(\mathrm{Mg})-\mathrm{SO}_{4}$. Due to the effect of evapoconcentration, water types of Tibetan lakes showed a gradient variation in the order of Ca ( Na) $-\mathrm{HCO}_{3}-\mathrm{Na}(\mathrm{K})-\mathrm{SO}_{4}-\mathrm{Na}(\mathrm{K})-\mathrm{Cl}$ along the southeast-northwest transect. Compared with the pre-1990s data, the concentrations of major ions in the majority of the lakes decreased and the water type of several lakes also changed. The variation of major ions and water types of Tibetan lakes indicated an obvious response in lake water chemistry to the regional climatic changes over decades.

Keywords: Tibet; lake water; major ions; distribution; response; regional climate

* 国家自然科学基金项目 $(41225002,41371088)$ 和中国科学院战略性先导科技专项 (B 类) (XDB03030504)联合资 助.2015 - 05-19 收稿;2015-11-13 收修改稿.李承鼎( 1987 ), 男, 硕士研究生; E-mail : lichengding@ itpcas.ac.cn.

** 通信作者;E-mail: qianggong.zhang@itpcas.ac.cn. 
湖泊水化学组成受到大气沉降、岩石风化、水体生物和人类活动等诸多因素的影响 ${ }^{[1-4]}$. 水体离子组成 是水化学性质的重要方面, 研究湖泊水体化学离子特征, 对于理解湖泊的补给方式、湖水的组成和来源具有 重要意义.

青藏高原是我国面积最大、世界海拔最高的高原, 主要包括西藏、青海和新疆, 以及四川、甘肃和云南的 少部分地区 ${ }^{[5]}$. 青藏高原分布着地球上海拔最高、数量最多、面积最大的湖泊群. 其中西藏地区拥有青藏高 原的大部分湖泊,并占到全国湖泊总数量和面积的 $30.9 \%$ 和 $35.1 \%{ }^{[6]}$. 对西藏湖泊水化学特征已有纳木错、 羊卓雍错和普莫雍错等湖泊的研究 ${ }^{[7-10]}$, 但缺少对整个西藏面上湖泊的综合研究. 青藏高原过去 30 年的升 温速率是全球升温速率的 2 倍, 为 $0.3^{\circ} \mathrm{C} /(10 \mathrm{a})$, 气候和环境发生了显著变化 ${ }^{[1-12]}$, 导致冰川、湖泊水量面积 的变化. 遥感研究表明 ${ }^{[13-14]}$, 青藏高原在近几十年冰川以退缩为主, 受冰川融水补给较大的湖泊面积扩张, 水位上升明显. 也有学者利用气象基础资料(气温和降水) 研究表明 ${ }^{[15]}$, 青藏高原除藏东地区, 其他区域气 候条件于 20 世纪末 21 世纪初由暖干向暖湿转变, 受其影响, 高原大型湖泊表现出水位上升、湖水离子浓度 减小的特征, 反映了气候暖湿条件下湖泊水量的增加. 在这一背景下, 研究湖泊水化学特征及其对区域气候 变化的响应显得尤为重要.

本研究选择青藏高原-西藏地区具有代表性的湖泊开展研究, 重点讨论其表层水体的主要离子组成、来 源、水体化学类型及其控制因素和对区域气候变化的响应, 为水体环境地球化学过程研究及其对全球气候 变化响应提供基础资料和科学依据.

\section{1 材料与方法}

\section{1 研究区域概况}

青藏高原在我国境内面积将近 $250000 \mathrm{~km}^{2}$, 平均海拔 $4000 \sim 5000 \mathrm{~m}$, 有 “亚洲水塔” ${ }^{[16]}$ 和 “第三极”之 称 ${ }^{[17-18]}$. 湖泊总面积约占全国湖泊总面积的 $51.4 \%{ }^{[6]}$, 并以咸水湖和盐湖为主 ${ }^{[19]}$. 湖泊水化学类型主要为 碳酸盐型、硫酸钠亚型、硫酸镁亚型和氯化物型 ${ }^{[20]}$. 青藏高原的主体部分之一是西藏地区, 其湖泊又分为 3 个区: 藏东南湖区、藏南湖区和藏北湖区. 上述湖区中除藏东南和藏南有少数外流湖区外, 其余皆为内流湖. 其中, 藏南和藏东南湖区湖面积占整个西藏湖泊总面积的 $11.53 \%$, 藏北湖区湖泊面积占整个西藏湖泊总面 积的 $88.47 \%$, 著名的纳木错就分布在此区域内 ${ }^{[21]}$. 西藏地区冬季气候寒冷, 夏季温凉, 且降水量东西差别较 大, 东部部分区域年均降水量能达到 $360 \mathrm{~mm}$, 中部年均降水量可以达到 $180 \mathrm{~mm}$, 而西部年均降水量只有 75 $\mathrm{mm}^{[22]}$. 其特殊的地理环境导致了该区的温度和水分条件具有自东南向西北变化的特征,致使该区东部为高 寒草甸区, 中部为高寒草原区, 西部为高寒荒漠区 ${ }^{[23-24]}$. 同时, 由于该地区很少受到人类活动干扰, 并且湖泊 多为内陆封闭型湖泊,因此该区的湖泊真实而完整地记录了该地区自然地理和气候环境变化的信息 ${ }^{[15,25]}$.

\section{2 样品采集与分析测试}

于 2009 和 2010 年对西藏 34 个湖泊水体进行系统的野外考察和采样 (图 1). 东西向采样主要沿 $32^{\circ} \mathrm{N}$ 附近的黑阿公路, 东起安多, 西至改则. 南北向采样主要沿 $85^{\circ} \mathrm{E}$ 附近的省道 206 线, 北起洞错, 南至冈底斯 山. 每个湖泊的采样点都远离河口, 所采水样均为表层湖水. 采集样品时佩戴一次性 PE 手套, 用采样湖泊水 体将预先用超纯水清洗过的 $100 \mathrm{ml}$ 聚乙烯瓶冲洗 3 次后装样, 低温冷藏保存, 并迅速运送至实验室待分析. 野外用超纯水按照采样的方法和流程做野外空白. 采用美国便携式水质参数仪 (HACH Hydrolab) 现场测定 湖泊水体的 $\mathrm{pH}$ 值.

所有样品分析测试在中国科学院青藏高原环境变化与地表过程重点实验室完成. 冷冻保存的样品在室 温下解冻后, 用 Dionex ISC 2000 和 Dionex ISC 2500 型离子色谱仪分别对主要阳离子 $\left(\mathrm{Na}^{+} 、 \mathrm{~K}^{+} 、 \mathrm{Ca}^{2+} 、 \mathrm{Mg}^{2+}\right)$ 和 主要阴离子 $\left(\mathrm{Cl}^{-} 、 \mathrm{SO}_{4}^{2-}\right)$ 进行测试. 其中, 离子色谱仪检测线低于 $1 \mu \mathrm{g} / \mathrm{L}$. 空白样品的分析结果显示, 样品在 采集、运输和分析测试过程中未受到污染. 测试结果见附表 1 .

所采样湖泊水体中 $\mathrm{NO}_{3}^{-}$和 $\mathrm{NH}_{4}^{+}$浓度低于仪器检测限, 故在本研究中没有讨论 ${ }^{[20,26]}$. 利用离子平衡法和 碳酸在水体中 $\left(25^{\circ} \mathrm{C}\right)$ 的电离平衡方程和常数 $(\mathrm{K})$ 估算 $\mathrm{HCO}_{3}^{-}$和 $\mathrm{CO}_{3}^{2-}$ 浓度 ${ }^{[27-30]}$, 总溶解性固体 (TDS) 浓度利 用离子浓度总和 (包括通过离子平衡估算的 $\mathrm{HCO}_{3}^{-}$和 $\mathrm{CO}_{3}^{2-}$ 浓度) 计算 ${ }^{[8]}$. 


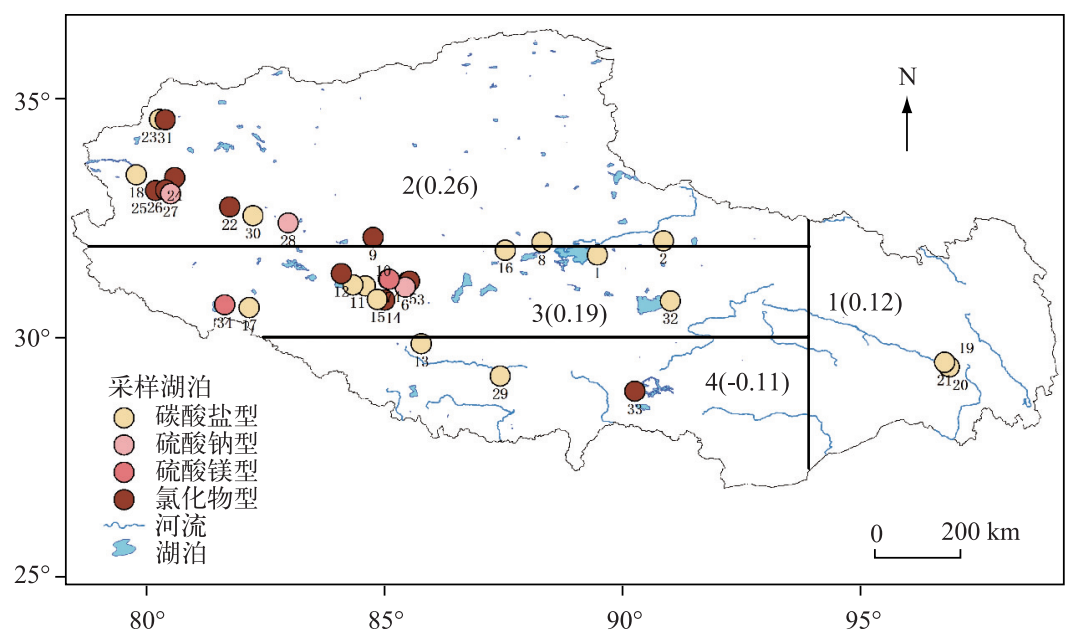

图 1 本研究选取的西藏 34 个湖泊采样点分布

(湖泊编号 $(1 \sim 34)$ 与表 1 一致; 1(0.12)、2(0.26)、3(0.19) 和 4(-0.11) 为 Zhang 等 ${ }^{[31]}$ 根据湖泊地理位置和 水位变化趋势划分的 4 个区域,括号里的数据代表相应区域的扩张速率分别为 $0.12 、 0.26 、 0.19$ 和 $-0.11 \mathrm{~m} / \mathrm{a}$.)

Fig. 1 Distribution of the 34 sampling lakes in the Tibet

\section{2 结果与讨论}

\section{1 湖泊水化学指标概况}

对采集的 34 个湖泊水样分析表明, 其水质参数以及主要离子含量存在显著差异 (附表 1), 湖泊水体主 要离子浓度和 TDS 浓度跨度范围较大, $\mathrm{pH}$ 值跨度范围较小. 从东南到西北, 就单个湖泊而言, 然乌湖 (19、 $20 、 21)$ 的 $\mathrm{Na}^{+} 、 \mathrm{NH}_{4}^{+} 、 \mathrm{~K}^{+} 、 \mathrm{Mg}^{2+} 、 \mathrm{Cl}^{-}$和 $\mathrm{SO}_{4}^{2-}$ 浓度最低, 齐格错 $(5)$ 的 $\mathrm{pH}$ 值最大, 敒布错 $(15)$ 的 $\mathrm{Ca}^{2+}$ 浓度最低, 扎布耶茶卡 (12) 的 TDS、 $\mathrm{Na}^{+} 、 \mathrm{~K}^{+}$和 $\mathrm{Cl}^{-}$浓度最高, 班戈错 (1) 的 $\mathrm{HCO}_{3}^{-}$浓度最高, 热邦错 (27) 的 $\mathrm{SO}_{4}^{2-}$ 浓度最 高, 龙木错 $(31)$ 的 $\mathrm{pH}$ 值最小, $\mathrm{Mg}^{2+}$ 和 $\mathrm{Ca}^{2+}$ 浓度最高. 根据现场考察得知, 然乌湖 (19、20、21) 是以冰川补给 为主的开放式湖泊, 水体中的大部分离子浓度都较低. 从本研究结果看, 封闭式湖泊水体中的离子浓度普遍 高于开放式湖泊中的离子浓度.

所采集的 34 个湖泊表层水体离子浓度高于我国和世界其他地区湖泊, 部分甚至高出 2 个数量级, 与全 球淡水平均值相比, 更是高出 3 个数量级 (附表 2). 湖泊水体中离子浓度的不同反映了湖泊矿化度的不同, 而湖泊矿化度的区域差异是自然环境和湖泊区域特征相结合的产物.

前人研究均表明 ${ }^{[10,32-33]}$, 青藏高原内陆湖泊在降水较少的干旱条件下, 湖水被强烈蒸发浓缩, 导致湖泊 矿化度在区域上的差异. 如潘红叕等 ${ }^{[32]}$ 认为,3 种因素导致我国西部和西北部湖泊矿化度异常分布的格局, 即太阳辐射、海拔高度和季风气候. 如, 以扎布耶茶卡 (年蒸发量 $2269.1 \mathrm{~mm}$, 年降水量 $192.6 \mathrm{~mm}$ ) 为代表的 湖泊受蒸发浓缩的影响, 矿化度达到 $439.8 \mathrm{~g} / \mathrm{L}$ 的高值 ${ }^{[33]}$. 青藏高原湖泊主要离子的分布同样也受到蒸发浓 缩的影响, 如鞠建廷等 ${ }^{[10]}$ 对藏南普莫雍错流域水体研究发现, $\mathrm{Ca}^{2+}$ 和 $\mathrm{Mg}^{2+}$ 是阳离子中的主要组成部分, 但是 $\mathrm{Ca}^{2+}$ 和 $\mathrm{Mg}^{2+}$ 的摩尔比例却严重失衡, 这是因为湖水在强烈的蒸发浓缩的过程中, $\mathrm{Ca}^{2+}$ 以碳酸钙的形式沉淀下 来, 从而导致 $\mathrm{Mg}^{2+}$ 浓度相对升高.

\section{2 离子来源主控因子分析}

岩石和土壤的分化分解, 以及大气的输人 (或沉降) 是天然水体中可溶性离子的 2 个主要来源 ${ }^{[1,34]}$. Gibbs ${ }^{[1]}$ 通过对世界雨水、河水、湖水等地表水化学组分分析, 利用 $\mathrm{TDS}-\mathrm{Na}^{+} /\left(\mathrm{Na}^{+}+\mathrm{Ca}^{2+}\right)$ 图, 划分出地表水 化学组分的 3 个控制端元: 岩石风化主控端元、大气降水主控端元和蒸发/结晶主控端元 (图 2). 本研究的 湖泊大部分位于 Gibbs 图中蒸发浓缩的区域, 说明该区大部分湖泊主要受到蒸发浓缩的控制( 图 3 ). 还有一 
部分靠近岩石风化主控端元, 说明这部分湖泊水体的可溶性离子主要受岩石风化控制. 另外一部分湖泊不在 Gibbs 分布模型内, 可能是因为湖水中具有较高浓度的 $\mathrm{Na}^{+}$和 TDS, 而 $\mathrm{Ca}^{2+}$ 发生了沉淀, 使得 $\mathrm{Na}^{+} /\left(\mathrm{Na}^{+}+\mathrm{Ca}^{2+}\right)$ 较大而引起,这与 Zhang 等 ${ }^{[8]}$ 对纳木错湖水离子特征的研究得到的结果一致.

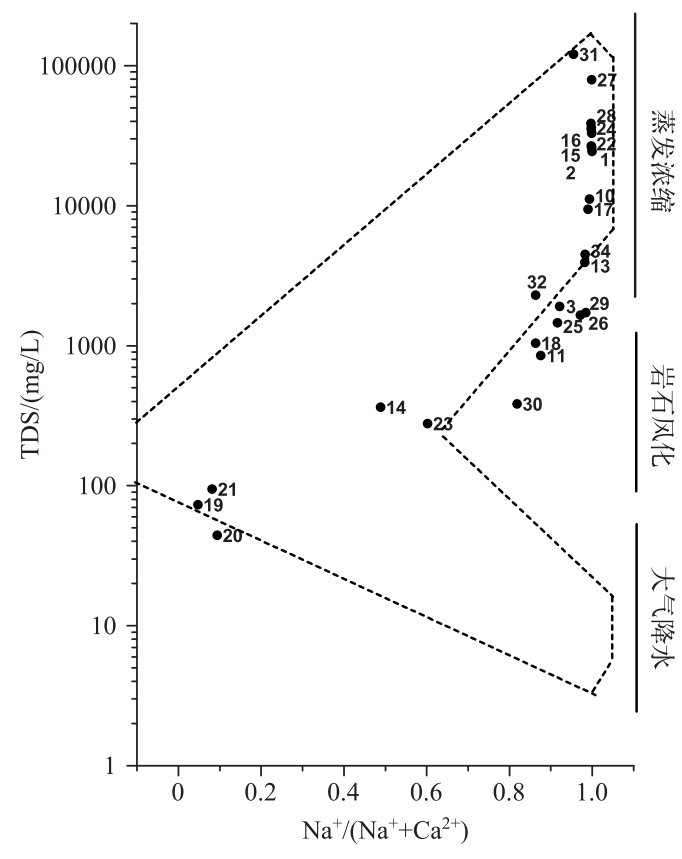

图 2 本研究西藏湖泊的 Gibbs 图式 (湖泊编号与附表 1 一致)

Fig. 2 Gibbs diagram of the studied lakes in the Tibet

\section{3 湖水化学类型分析}

从淡水湖到咸水湖再到盐湖, 直至干盐湖结束演 化是湖泊自然演化的一般趋势, 其水化学类型也遵循 一定的演化规律: 即为碳酸盐型-硫酸盐型-硫酸镁 型-氯化物型 ${ }^{[4,35]}$. 基于 Piper 图解 (图 3), 可以将 34 个湖泊划分为 $\mathrm{Ca}-\mathrm{HCO}_{3}\left(\mathrm{~B}\right.$ 区) 、 $\mathrm{Na}-\mathrm{HCO}_{3}(\mathrm{D}$ 区)、Ca $(\mathrm{Mg})-\mathrm{SO}_{4}$ ( A 区) 和 $\mathrm{Na}(\mathrm{K})-\mathrm{Cl}$ ( C 区 ) 型. 西藏 34 个湖 泊绝大部分位于 Piper 图中的 $\mathrm{C}$ 区, 即氯化物型 ( $\mathrm{Na}$ (K) - Cl) 湖泊, 表明大部分湖泊处于湖泊演化的后期; 其中齐格错 (5)、扎仓茶卡 (30)、嘎仁错 (14) 和松木 希错 (23) 则主要位于 A 区, 湖水水化学类型为 $\mathrm{Ca}$ $(\mathrm{Mg})-\mathrm{SO}_{4}$ 型, 说明这 4 个湖泊处于湖泊演化的中间阶 段; 纳木错 (32) 和然乌湖 (19、20、21) 则处于 Piper 图 中的 $\mathrm{B}$ 区, 为 $\mathrm{HCO}_{3}$ - $\mathrm{Ca}$ 型湖泊; 班公错 (18)、塔若错 (11)、麦穷错 (10)、昆仲错 (26)、打加错 (13)、达则错 (16)、兹格塘错 (2)、塞布错 ( 8) 和朗错 (29) 位于 D 区, 水化学类型为 $\mathrm{Na}-\mathrm{HCO}_{3}$ 型, 这些湖泊处于湖泊演 化的初期阶段.

本研究湖泊水体化学类型的分布与郑绵平等 ${ }^{[36]}$ 对青藏高原湖泊水化学类型的划分区域基本一致, 即 从东南到西北依次为碳酸盐型-硫酸钠型-硫酸钾型氯化物型(图 1), 与青藏高原宏观空间尺度上的从东 南到西北的干燥度 ${ }^{[37]}$ 和湿润-半湿润-半干旱-干旱-

极干旱的气候区划相吻合 ${ }^{[38]}$, 进一步说明青藏高原南部湖泊受到蒸发浓缩作用的影响, 使得湖泊中的离子 组成和水化学类型发生了空间上的递变.

\section{4 近几十年湖泊水体离子浓度变化及其对区域气候变化的响应}

1990s 以前, 科考人员对我国的湖泊进行实地勘测, 得到一批重要的湖泊水化学数据 ${ }^{[33]}$. 为了探讨本次 研究涉及湖泊的水化学特征在近几十年来的变化及其对区域气候变化的响应, 选取其中 16 个湖泊, 对比分 析近几十年其离子浓度和组成的变化 (图 4). 结果显示, 大多数湖泊中主要离子浓度在几十年间有所降低. 个别湖泊如班戈错、昂古错、嘎仁措和扎仓茶卡, 出现大幅度、乃至数量级的下降, 同时 TDS 浓度也表现为显 著下降趋势. 受物源输人和湖泊过程影响, 湖水离子浓度可能在季节尺度上发生变化, 如王君波等 ${ }^{[7]}$ 对纳木 错不同月份的水体采样分析发现, 纳木错湖泊水体离子浓度具有季节变化特征, 但并未出现数量级的差别. 本研究中多数湖泊离子浓度较低于 1990s 前的浓度,并且部分湖泊 (如嘎仁错、扎仓茶卡和芒错等) 出现了 数量级降低, 这表明湖泊水体近几十年来表现出淡化的趋势. 全球气温升高已成为不可否认的事实, 冰川退 缩加剧也已得到国际社会的高度关注. 姜永见等 ${ }^{[15]}$ 的研究表明, 从 1980s 到 21 世纪初, 青藏高原中东部地 区年均气温呈年代际递增的变化趋势, 年可利用降水量也呈递增的趋势. 湖水离子浓度下降幅度较大的 4 个湖泊 (班戈错、昂古错、嘎仁错和扎仓茶卡) 均处于青藏高原中部的羌塘高寒草原半干旱气候区. 其中扎仓 茶卡为封闭式的湖泊, 没有常年性河流补给, 主要依靠大气降水和地下水补给, 年降水量稀少. 扎仓茶卡可 能随着降水量的增加, 湖泊水量增加, 导致了湖泊中离子浓度的降低. 其余 3 个湖泊均主要依靠地表径流和 人湖河流补给, 且降水量较为丰富, 年均降水量均超过 $200 \mathrm{~mm}$. 其中班戈错位于主要靠冰川融水补给的色 林错流域, 已有研究表明 ${ }^{[39]}$, 色林错流域的冰川在逐年退缩的同时, 湖泊面积在逐年增加, 可见班戈错在受 

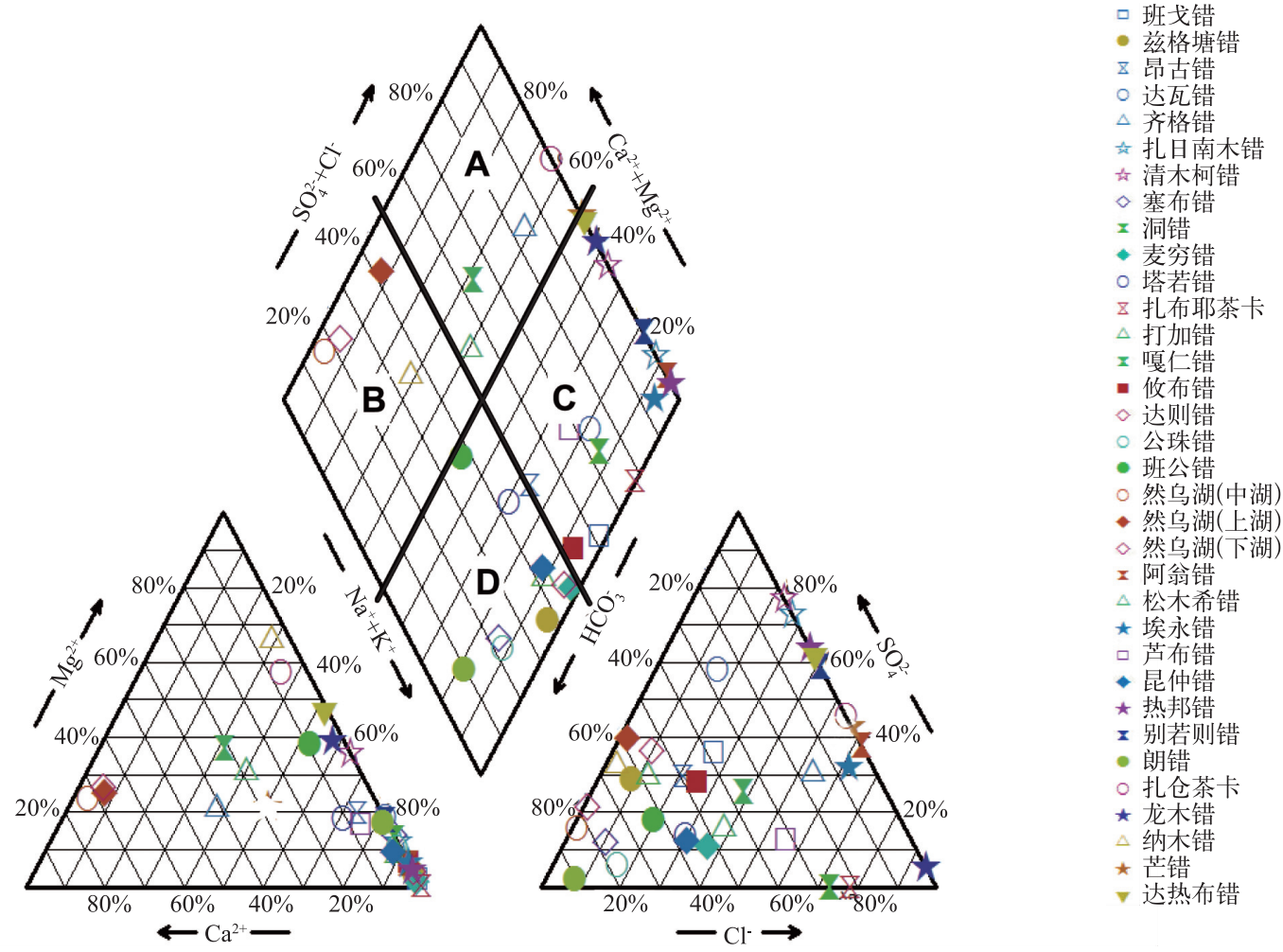

图 3 西藏 34 个西藏湖泊离子浓度 Piper 图

Fig.3 Piper diagram of ionic concentration in water samples from the 34 lakes over the Tibet

到降水影响的同时,也受到冰川融水的影响,使得离子浓度降低. 同样昂古错和嘎仁错在受到降水量影响的 同时也受到冰川融水的影响, 从而使得湖水中离子浓度降低. 但由于受到湖泊流域面积、体积和扩张速率的 影响,不同湖泊水体离子变化幅度有所差异.

湖泊水化学类型的对比分析表明 (附表 1),近几十年来,大部分湖泊水化学类型没有发生显著变化. 值 得注意的是, 洞错 (9)、扎布耶茶卡 (12)、阿翁错 (22)、扎仓茶卡 (30) 和龙木错 $(31)$ 水化学类型变化较大. 其中, 洞错 (9)、扎布耶茶卡 (12)、扎仓茶卡 $(30)$ 和龙木错 (31) 由硫酸盐型转变为氯化物型, 说明蒸发浓缩 加剧, 导致了湖泊向氯化物型湖泊的演化; 阿翁错 (22) 则由碳酸盐型转变为氯化物型, 亦表明湖泊水化学的 加速演化. 但是麦穷错 (10) 则由硫酸型湖泊向碳酸型湖泊发生了演化, 可能是该区域径流或者降雨的输人 增加所致. 湖泊的蒸发浓缩过程在影响湖泊水体离子浓度的同时也影响了湖泊面积的变化, 类延斌等 ${ }^{[40]}$ 就 指出兹格塘错的面积和离子浓度变化与湖泊的蒸发浓缩关系密切. 其中部分以扎仓茶卡为代表的湖泊较为 特殊, 其湖泊离子浓度在降低的同时, 湖泊的水化学类型却在蒸发浓缩的作用下, 向氯化物型湖泊演化, 说 明湖泊水量增加导致的湖泊淡化对湖泊离子浓度变化的影响大于气温增加蒸发浓缩导致的湖泊咸化的 影响.

相关研究指出 1999-2009 年青藏高原的湖泊面积处于急剧扩张时期 ${ }^{[13,41]}$. 姜永见等 ${ }^{[15]}$ 研究指出, 青藏高 原除藏东地区外,其他地区气候条件于 20 世纪末 21 世纪初由暖干向暖湿转变, 受其影响, 以青海湖、鄂陵湖、 冬给措纳、兹格塘错为代表的高原大型湖泊水量增加,致使湖泊出现水位上升、湖泊水体离子浓度减小的特征. Zhang 等研究青藏高原 111 个湖泊 2003-2009 年湖面的变化趋势, 将青藏高原的湖泊划分为 4 个区(图 1), 其 中 $1 、 2$ 和 3 区湖泊以扩张为主, 扩张速率分别为 $0.12 、 0.26$ 和 $0.19 \mathrm{~m} / \mathrm{a}, 4$ 区湖泊以萎缩为主, 速率为 -0.11 $\mathrm{m} / \mathrm{a}^{[31]}$. 本研究中离子浓度降低的湖泊与湖泊扩张区域基本吻合, 且主要集中在 2 区和 3 区. 以兹格塘错为 

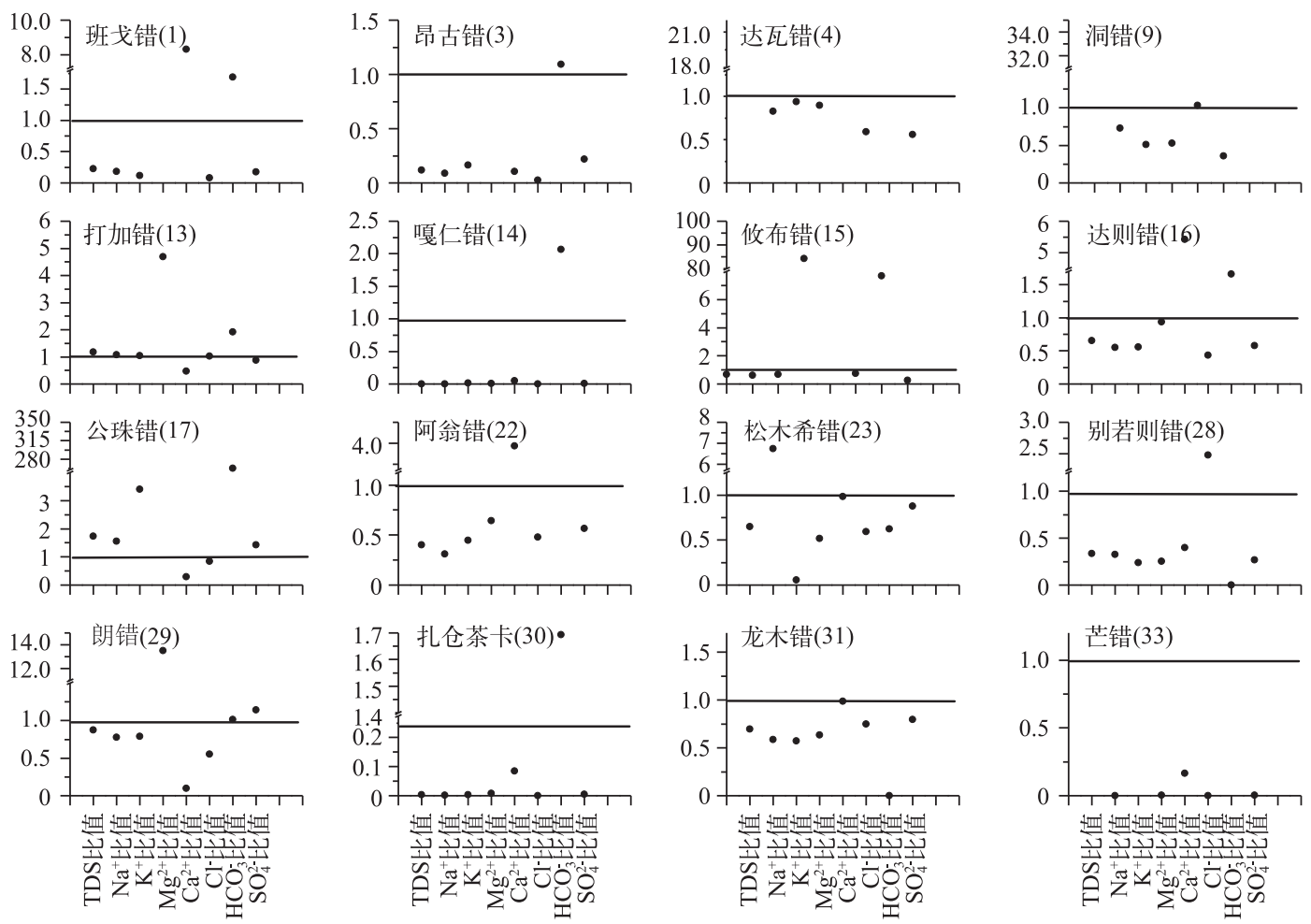

图 4 西藏 16 个湖泊离子浓度与 1990s 前离子浓度比率(1990s 前湖泊离子数据来源于《中国湖泊志》 ${ }^{[33]}$, 采集时间分别为:班戈错 1975 年, 昂古错 1980 年,达瓦错 1980 年,洞错 1978 年,打加错 1980 年, 嘎仁错 1978 年,敒布错 1960s, 达则错 1976 年,公珠错 1960s, 阿翁错 1978 年,松木希错 1987 年, 别若则错 1976 年, 朗错 1980 年, 扎仓茶卡 1978 年, 龙木错 1978 年, 芒错 1984 年)

Fig.4 Comparison of ionic concentration from our sites with previous studies before 1990s

例, 前人研究表明, 该湖自 1999 年后湖水中主要离子和 TDS 浓度都有减小的趋势, 湖泊的体积在增大 ${ }^{[15,40]}$; 类 延斌等在 1998、2002 和 2006 年的实地考察也证实了近年来湖泊水位的持续上涨 ${ }^{[40]}$. 兹格塘错从 1999 、2006 和 2007-2009 年, 湖泊的 TDS 和离子浓度整体呈现出逐步降低的趋势 (表 1), 反映了湖泊扩张对湖水化学的影 响. 在区域气温不断升高, 冰川融解退缩、多年冻土退化和地下水融化的背景下, 以冰川径流, 冻土水分释放和 地下水补给为主的湖泊扩张淡化 ${ }^{[14,42]}$, 从而使得湖泊中离子的浓度有所下降. 综上所述, 本研究中湖泊离子浓 度特征及其水化学类型的变化反映了过去几十年西藏湖泊水化学对区域气候变化的响应.

表 1 兹格塘错不同年份水化学组成的变化

Tab.1 Chemical composition of water of Zige Tangco in 1999,2006,2007 and 2009

\begin{tabular}{cccccccccc}
\hline $\begin{array}{c}\text { 时间 } \\
(\text { 年 })\end{array}$ & $\begin{array}{c}\mathrm{Na}^{+} / \\
(\mathrm{mg} / \mathrm{L})\end{array}$ & $\begin{array}{c}\mathrm{K}^{+} / \\
(\mathrm{mg} / \mathrm{L})\end{array}$ & $\begin{array}{c}\mathrm{Mg}^{2+} / \\
(\mathrm{mg} / \mathrm{L})\end{array}$ & $\begin{array}{c}\mathrm{Ca}^{2+} / \\
(\mathrm{mg} / \mathrm{L})\end{array}$ & $\begin{array}{c}\mathrm{Cl}^{-} / \\
(\mathrm{mg} / \mathrm{L})\end{array}$ & $\begin{array}{c}\mathrm{SO}_{4}^{2-} / \\
(\mathrm{mg} / \mathrm{L})\end{array}$ & $\begin{array}{c}\mathrm{HCO}_{3}^{-} / \\
(\mathrm{mg} / \mathrm{L})\end{array}$ & $\begin{array}{c}\mathrm{TDS} / \\
(\mathrm{g} / \mathrm{L})\end{array}$ & 参考文献 \\
\hline 1999 & 12164 & 749 & 119.0 & 25.0 & 1497 & 8026 & 14584 & 33.23 & {$[15]$} \\
1999 & 12170 & 757 & 121.6 & 9.0 & 1491 & 8070 & - & 40.70 & {$[40]$} \\
2006 & 7426 & 520 & 111.0 & 2.5 & 1020 & 4850 & 2450 & 19.70 & {$[15]$} \\
2006 & 7388 & 498 & 117.8 & 2.5 & 980 & 5160 & - & 21.20 & {$[40]$} \\
2007 & 9230 & 466 & 52.0 & 20.0 & 774 & 5840 & - & 24.50 & {$[40]$} \\
2009 & 7046 & 485 & 147.0 & 5.0 & 1002 & 4573 & 6846 & 17.71 & 本研究 \\
\hline
\end{tabular}


然而, 并非所有湖泊离子均在过去几十年发生淡化现象, 其中打加错和公珠错的 TDS 和部分离子浓度 $\left(\mathrm{Na}^{+} 、 \mathrm{~K}^{+} 、 \mathrm{Mg}^{2+} 、 \mathrm{HCO}_{3}^{-}\right)$呈现不同程度的升高, 而且其水化学类型在近几十年并未发生显著变化. 打加错 (13) 位 于青藏高原的中南部 (图 1), 四面环山, 主要依靠地表径流和冰雪融水径流补给, 其主要人湖河流有 21 条 ${ }^{[33]}$. 而公珠错 (17) 也位于青藏高原的中南部, 同样四面环山, 且主要依靠地表径流补给, 其主要人湖河流 有 16 条 ${ }^{[33]}$, 表明这 2 个湖泊的补给量较大. 但研究表明 ${ }^{[43]}$, 从 1974- 2003 年, 公珠错的面积一直在减少, Zhang 等的研究表明, 2003-2009 年,公珠错的退缩速率为 $-0.04 \mathrm{~m} / \mathrm{a}^{[31]}$. 打加错在过去几十年中的退缩/扩 张尚不明确. 作为一个封闭湖泊, 湖水中的 $\mathrm{Mg}^{2+} 、 \mathrm{Ca}^{2+}$ 和 $\mathrm{HCO}_{3}^{-}$主要来源于碳酸盐和 (或) 蒸发岩的风化. 打加 错 $\mathrm{Mg}^{2+}$ 和 $\mathrm{HCO}_{3}^{-}$离子浓度升高很多 (图 4), 可能来源于径流增加携带人更多碳酸岩和 (或) 蒸发岩的风化物. 但是 $\mathrm{Ca}^{2+}$ 浓度明显较少, 一般而言, 在封闭湖盆中, $\mathrm{Mg}^{2+}$ 和 $\mathrm{Ca}^{2+}$ 的摩尔比值不会超过 $1^{[44]}$, 但是打加错的 $\mathrm{Mg}^{2+}$ 和 $\mathrm{Ca}^{2+}$ 的摩尔比值 (4.99) 很高. 同理, 公珠错虽无 $\mathrm{Mg}^{2+}$ 比率数据 (图 4), 但 $\mathrm{Ca}^{2+}$ 和 $\mathrm{HCO}_{3}^{-}$浓度变化与打 加错明显一致. 这表明可能是由于湖水在强烈蒸发浓缩的过程中, 由于钻盐在水中的溶解度小于镁盐 ${ }^{[45]}$, $\mathrm{Ca}^{2+}$ 以碳酸钙的形式沉积下来, 从而导致 $\mathrm{Mg}^{2+}$ 和 $\mathrm{Ca}^{2+}$ 的摩尔比值偏高. 由此得出, 西藏部分湖泊受到强烈的 蒸发浓缩作用的影响, 从而使得部分离子浓度有了一定程度的升高.

\section{3 结论}

1) 西藏湖泊水体的水质参数和主要离子浓度存在显著空间差异, 大多数湖泊水体中的主要离子浓度远 高于全国乃至全球其他地区. 封闭式湖泊水体中离子浓度普遍高于以冰川补给为主的开放式湖泊水体.

2) 西藏湖泊水体离子主要受到蒸发浓缩的影响. 大多数湖泊的水化学类型为氯化物型, 其次为碳酸盐 型, 少部分为硫酸盐型. 水化学类型从东南到西北依次为碳酸盐型-硫酸钠型-硫酸钾型-氯化物型.

3) 从 1990s 初到 2009 年间, 西藏大部分湖泊水化学类型没有发生显著变化, 但由于蒸发浓缩的加剧, 少 数湖泊水化学类型, 向氯化物型转变. 在全球和区域气候变化的影响下, 大部分湖泊水体的主要离子浓度较 1990s 前都有了一定的降低, 反映湖泊水化学对区域气候环境变化的响应. 但是由于受到湖泊流域面积、湖 泊体积和扩张速率的影响,离子变化幅度有所差异.

致谢: 感谢宗继彪和赵瑞的协助, 同时感谢中国科学院纳木错观测站的支持.

\section{4 参考文献}

[ 1 ] Gibbs RJ. Mechanisms controlling world water chemistry. Science, 1970, 170(3962) : 1088-1090.

[ 2 ] Kilham P. Mechanisms controlling the chemical composition of lakes and rivers: Data from Africa. Limnology and Oceanography, 1990, 35(1): 80-83.

[ 3 ] Hou Zhaohua, Xu Hai, An Zhisheng. Major ion chemistry of waters in Lake Qinghai catchment and the possible controls. Earth and Environment, 2009, 37(1) : 11-19(in Chinese with English abstract). [侯昭华, 徐海, 安芷生. 青海湖流域 水化学主离子特征及控制因素初探. 地球与环境, 2009, 37(1): 11-19.]

[ 4 ] Wang Peng, Shang Yingnan, Shen Licheng et al. Characteristics and evolution of hydrochemical compositions of freshwater lake in Tibetan Plateau. Environmental Science, 2013, 34(3): 874-881 (in Chinese with English abstract). [王鹏, 尚英 男, 沈立成等. 青藏高原淡水湖泊水化学组成特征及其演化. 环境科学, 2013, 34(3): 874-881.]

[ 5 ] Zhang Yili, Li Bingyuan, Zheng Du. A discussion on the boundary and area of the Tibetan Plateau in China. Geographical Research, 2002, 21 (1) : 1-8( in Chinese with English abstract). [张镱锂, 李炳元, 郑度. 论青藏高原范围与面积. 地 理研究, 2002, 21(1): 1-8.]

[ 6 ] Ma Ronghua, Yang Guishan, Duan Hongtao et al. China's lakes at present: Number, area and spatial distribution. Science China: Earth Science, 2011, 41(3): 394-401 (in Chinese with English abstract). DOI 10.1007/s11430-010-4052-6. [马荣华, 杨桂山, 段洪涛等. 中国湖泊的数量, 面积与空间分布. 中国科学: 地球科学, 2011, 41(3): 394-401.]

[ 7 ] Wang Junbo, Ju Jianting, Zhu Liping. Water chemistry variations of lake and inflowing rivers between preand post-monsoon season in Nam Co, Tibet. Scientia Geographica Sinica, 2013, 33(1) : 90-96( in Chinese with English abstract). [王君 波, 鞠建廷, 朱立平. 季风期前后西藏纳木错湖水及人湖河流水化学特征变化. 地理科学, 2013, 33(1): 90-96.]

[ 8 ] Zhang Qianggong, Kang Shichang, Wang Feiyue et al. Major ion geochemistry of Nam Co lake and its sources, Tibetan 
Plateau. Aquatic Geochemistry, 2008, 14(4): 321-336.

[ 9 ] Zhang Xueqin, Sun Rui, Zhu Liping. Lake water in the Yamzhog Yumco Basin in south tibetan region: Quality and evaluation. Journal of Glaciology and Geocryology, 2012, 34(4) : 950-958(in Chinese with English abstract). [张雪芹, 孙 瑞, 朱立平. 藏南羊卓雍错流域主要湖泊水质状况及其评价. 冰川冻土, 2012, 34(4): 950-958.]

[10] Ju Jianting, Zhu Liping, Wang Yong. Composition, spatial distribution and environmental significance of water ions in Pumayum Co and its catchment, southern Tibet. J Lake Sci, 2008, 20(5) : 591-599(in Chinese with English abstract). DOI 10.18307/2008.0507. [蘜建廷, 朱立平, 汪勇等. 藏南普莫雍错流域水体离子组成与空间分布及其环境意义. 湖泊科学, 2008, 20(5): 591-599.]

[11] Xu BQ, Cao JJ, James HS et al. Black soot and the survival of Tibetan glaciers. Proceedings of the National Academy of Sciences, 2009, 106(52): 22114-22118.

[12] Kang SC, Xu YW, You QL et al. Review of climate and cryospheric change in the Tibetan Plateau. Environmental Research Letters, 2010, 5(1): 015101.

[13] Wan Wei, Xiao Pengfeng, Feng Xuezhi et al. Remote sensing analysis for changes of lakes in the southeast of Qiangtang area, Qinghai-Tibet Plateau in recent 30 years. J Lake Sci, 2010, 22(6): 874-881 (in Chinese with English abstract). DOI 10.18307/2010.0609. [万玮, 肖鹏峰, 冯学智等. 近 30 年来青藏高原芫塘地区东南部湖泊变化遥感分析. 湖 泊科学, 2010, 22(6): 874-881.]

[14] Li Zhiguo. Glacier and lake changes across the Tibetan Plateau during the past 50 years of climate change. Journal of Resources and Ecology, 2012, 27(8): 1431-1443(in Chinese with English abstract). [李治国. 近 50 年气候变化背景下 青藏高原冰川和湖泊变化. 自然资源学报, 2012, 27(8) : 1431-1443.]

[15] Jiang Yongian, Li Shijie, Shen Defu et al. Climate change and its impact on the lake environment in Tibetan Plateau in 1971 - 2008. Scientia Geographica Sinica, 2012, 32(12): 1503-1512(in Chinese with English abstract). [姜永见, 李 世杰, 沈德福等. 青藏高原近 40 年来气候变化特征及湖泊环境响应. 地理科学, 2012, 32(12): 1503-1512.]

[16] Lu CX, Yu G, Xie GD. Tibetan plateau serves as a water tower. IEEE, 2005, 5: 3120-3123.

[17] Jane Qiu. China: the third pole. Nature, 2008, 454(7203): 393-396.

[18] Zhang Xin, Wu Yanhong. Water level variation of inland lakes on the south-central Tibetan Plateau in 1972 - 2012. Acta Geographica Sinica, 2014, 69(7) : 993-1001 (in Chinese with English abstract). [张釒金, 吴艳红. 1972-2012 年青藏 高原中南部内陆湖泊的水位变化. 地理学报, 2014, 69(7): 993-1001.]

[19] Jiang Jiahu, Huang Qun. Distribution and variation of lakes in Tibetan Plateau and their comparison with lakes in other part of China. Water Resources Protection, 2005, 20(6) : 24-27 (in Chinese with English abstract). [姜加虎, 黄群. 青藏 高原湖泊分布特征及与全国湖泊比较. 水资源保护, 2005, 20(6): 24-27.]

[20] Yu Shengsong, Tang Yuan. The hydrochemical characteristics of the saline lakes on Qinghai-Xizang Plateau. Oceanologia et Limnologia Sinica, 1981, 12(6) : 498-511(in Chinese with English abstract). [于昇松, 唐渊. 青藏高原盐湖的水化 学特征. 海洋与湖沼, 1981, 12(6) : 498-511.]

[21] Fan Yunqi. The supply coefficient of interior lakes in Xizang. Oceanologia et Limnologia Sinica, 1983, 14(2) : 118-127 (in Chinese with English abstract). [范云崎. 西藏内陆湖泊补给系数的初步探讨. 海洋与湖沼, 1983, 14(2)： 118-127.]

[22] Lei Yanbin, Yao Tandong, Zhang Enlou et al. Characteristics of $\delta^{13} \mathrm{C}_{\mathrm{DIC}}$ value in lakes on Qiangtang Plateau and its affected factors. J Lake Sci, 2011, 23(5) : 673-680 (in Chinese with English abstract). DOI 10.18307/2011.0502. [类延斌, 姚檀栋, 张恩楼等. 㒸塘高原湖水 $\delta^{13} \mathrm{C}_{\mathrm{DIC}}$ 值特征及影响因素分析. 湖泊科学, 2011, 23(5): 673-680.]

[23] Zhang Rongzu, Zheng Du, Yang Qinye et al eds. Physical geography of Tibet. Beijing: Science Press, 1982(in Chinese). [张荣祖, 郑度, 杨勤业等. 西藏自然地理. 北京: 科学出版社, 1982.]

[24] Lei YB, Yao TD, Sheng YW et al. Characteristics of $\delta^{13} \mathrm{C}_{\mathrm{DIC}}$ in lakes on the Tibetan Plateau and its implications for the carbon cycle. Hydrological Processes, 2012, 26(4) : 535-543.

[25] Li Shijie, Li Wanchun, Xia Weilan. The scientific expedition on the modern lake evolution in the Qinghai-Tibet plateau: A preliminary report. J Lake Sci, 1998, 10(4) : 95-96(in Chinese with English abstract). DOI 10. 18307/1998.0416. [李世杰, 李万春, 夏威岗. 青藏高原现代湖泊变化与考察初步报告. 湖泊科学, 1998, 10(4) : 95-96. ]

[26] Wang Junbo, Zhu Liping, Ju Jianting et al. Water chemistry of eastern Nam Lake area and inflowing rivers in Tibet. Scientia Geographica Sinica, 2009, 29(2): 288-293( in Chinese with English abstract). [王君波, 朱立平, 鞠建廷等. 西藏 
纳木错东部湖水及人湖河流水化学特征初步研究. 地理科学, 2009, 29(2): 288-293.]

[27] Mitamura O, Seike Y, Kondo K et al. First investigation of ultraoligotrophic alpine Lake Puma Yumco in the pre-Himalayas, China. Limnology, 2003, 4(3) : 167-175.

[28] Murakami T, Terai H, Yoshiyama Y et al. The second investigation of Lake Puma Yum Co located in the southern Tibetan Plateau, China. Limnology, 2007, 8(3) : 331-335.

[29] Pu Tao, He Yuanqing, Zhu Guofeng et al. Hydrochemical characteristics of three rivers around Yulong Mountain in rainy season. Scientia Geographica Sinica, 2011, 31(6): 734-740(in Chinese with English abstract). [蒲奉, 何元庆, 朱国 锋等. 玉龙雪山周边典型河流雨季水化学特征分析. 地理科学, 2011, 31(6): 734-740.]

[30] Guo Junming, Kang Shichang, Zhang Qianggong et al. Temporal and spatial variations of major ions in Nam Co lake water, Tibetan Plateau. Chinese Journal of Environmental Science, 2012, 33(7) : 2295-2302(in Chinese with English abstract). [ 郭军明, 康世昌, 张强弓等. 青藏高原纳木错湖水主要化学离子的时空变化特征. 环境科学, 2012, 33(7): 2295-2302. ]

[31] Zhang GQ, Xie HJ, Kang SC et al. Monitoring lake level changes on the Tibetan Plateau using ICES at altimetry data (2003-2009). Remote Sensing of Environment, 2011, 115(7) : 1733-1742.

[32] Pan Hongxi, Wang Sumin. Spatial distribution of mineralized degree of lakes in China. Oceanologia et Limnologia Sinica, 2001, 32(2) : 185-191 (in Chinese with English abstract). [潘红胥, 王苏民. 中国湖泊矿化度的空间分布. 海洋与湖 沼, 2001, 32(2) : 185-191.]

[33] Wang Sumin, Dou Hongshen. China lake records. Beijing: Science Press, 1998(in Chinese). [王苏民, 窦鸿身. 中国湖 泊志. 北京: 科学出版社, 1998.]

[34] Lasaga AC, Soler JM, Ganor J et al. Chemical weathering rate laws and global geochemical cycles. Geochimica et Cosmochimica Acta, 1994, 58(10): 2361-2386.

[35] Wang Hailei, Zheng Mianping. Preliminary study of the correlation between hydrochemistry and salinity of lakes in the Qinghai-Tibetan Plateau. Acta Geologica Sinica, 2010, 84(10): 1517-1522(in Chinese with English abstract). [王海 雷, 郑绵平. 青藏高原湖泊水化学与盐度的相关性初步研究. 地质学报, 2010, 84(10): 1517-1522.]

[36] Zheng Mianping, Liu Xifang. Hydrochemistry and minerals assemblages of salt lakes in the Qinghai-Tibet Plateau, China. Acta Geologica Sinica, 2010, 84(11) : 1585-1600(in Chinese with English abstract). [郑绵平, 刘喜方. 青藏高原盐湖 水化学及其矿物组合特征. 地质学报, 2010, 84(11): 1585-1600.]

[37] Sun Honglie, Liao Ke, Pan Yusheng et al eds. Atlas of the Qinghai-Tibet Plateau. Beijing: Science Press, 1990( in Chinese). [孙鸿烈, 廖克, 潘裕生等. 青藏高原地图集. 北京: 科学出版社, 1990.]

[38] Lin Zhenyao, Wu Xiangding. Climatic regionalization of the Qinghai-Xizang Plateau. Acta Geographica Sinica, 1981,36 (1) : 22-32 (in Chinese with English abstract). [ 林振耀, 吴祥定. 青藏高原气候区划. 地理学报, 1981, 36(1): 22-32.]

[39] Lu Anxin, Yao Tandong, Wang Lihong et al. Study on the fluctuations of typical glaciers and lakes in the Tibetan Plateau using remote sensing. Journal of Glaciology and Geocryology, 2005, 27(6) : 783-792(in Chinese with English abstract). [鲁安新, 姚檀栋, 王丽红等. 青藏高原典型冰川和湖泊变化遥感研究. 冰川冻土, 2005, 27(6) : 783-792.]

[40] Lei Yanbin, Zhang Hucai, Wang Shen et al. Change in lake area of Zigê Tangco on central Tibetan Plateau since the 1970s and its mechanisms. Journal of Glaciology and Geocryology, 2009, 31 (1) : 48-54(in Chinese with English abstract). [类延斌, 张虎才, 王甡等. 青藏高原中部兹格塘错 1970 年来的湖面变化及原因初探. 冰川冻土, 2009, 31( 1$)$ : 48-54.]

[41] Li Junli, Sheng Yongwei, Luo Jiancheng et al. Remotely sensed mapping of inland lake area changes in the Tibetan Plateau. J Lake Sci, 2011, 23(3) : 311-320(in Chinese with English abstract). DOI 10.18307/2011.0301. [李均力, 盛永 伟, 骆剑承等. 青藏高原内陆湖泊变化的遥感制图. 湖泊科学, 2011, 23(3): 311-320.]

[42] Wu Jichun, Sheng Yu, Wu Qingbai et al. Discussion on the possibility of taking ground ice in permafrost regions as water sources under climate warming. Journal of Glaciology and Geocryology, 2009, 31(2) : 350-356(in Chinese with English abstract). [ 吴吉春, 盛显, 吴青柏等. 气候变暖背景下青藏高原多年冻土层中地下冰作为水 “源” 的可能性探讨. 冰川冻土, 2009, 31(2): 350-356.]

[43] Guo Liuping, Ye Qinghua, Yao Tandong et al. The glacial landforms and the changes of glacier and lake area in the Mapam Yumco Basin in Tibetan Plateau based on GIS. Journal of Glaciology and Geocryology, 2007, 29(4) : 517-524(in 
Chinese with English abstract). [ 郭柳平, 叶庆华, 姚檀栋等. 基于 GIS 的玛旁雍错流域冰川地貌及现代冰川湖泊变 化研究. 冰川冻土, 2007, 29(4): 517-524.]

[44] Zhang J, Huang WW, Letolle R et al. Major element chemistry of the Huanghe (Yellow River), China-weathering processes and chemical fluxes. Journal of Hydrology, 1995, 168(1): 173-203.

[45] Shen Zhaoli, Zhu Wanhua, Zhong Zuosheng. Basis of hydrogeochemistry. Beijing: Geology Publishing House, 1993 (in Chinese). [沈照理, 朱宛华, 钟佐葲. 水文地球化学基础. 北京: 地质出版社, 1993.]

[46] Yao Shuchun, Xue Bin, Lü Xianguo et al. The hydrochemical characteristic of lakes in Songnen Plain. Wetland Science, 2010, 8(2) : 169-175 (in Chinese with English abstract). [姚书春, 薛滨, 吕宪国等. 松嫩平原湖泊水化学特征研究. 湿地科学, 2010, 8(2): 169-175.]

[47] Hu Chunhua, Zhou Wenbin, Xia Siqi. Characteristics of major ions and the influence factors in Poyang Lake catchment. Environmental Chemistry, 2011, 30(9)：1620-1626(in Chinese with English abstract). [胡春华, 周文斌, 夏思奇. 鄱 阳湖流域水化学主离子特征及其来源分析. 环境化学, 2011, 30(9): 1620-1626.]

[48] Chen Zihong. The chemical properties and development situation of northern lakes. Arid Environmetal Monitoring, 2000, 14(4) : 222-225 (in Chinese with English abstract). [ 陈子红. 北方湖泊水化学特征与发展态势. 干旱环境监测, $2000,14(4): 222-225$. ]

[49] Xu H, Hou ZH, An ZS et al. Major ion chemistry of waters in Lake Qinghai catchments, NE Qinghai-Tibet plateau, China. Quaternary International, 2010, 212(1): 35-43.

[50] Ye Hongmeng, Yuan Xuyin, Ge Minxia et al. Water chemistry characteristics and controlling factors in the northern rivers in Taihu Basin. Ecology and Environmental Sciences, 2010, 19(1): 23-27(in Chinese with English abstract). [ 叶宏萌, 袁旭音, 葛敏霞等. 太湖北部流域水化学特征及其控制因素. 生态环境学报, 2010, 19(1): 23-27.]

[51] Li Feng, Li Tianjie. Factors influencing the chemical composition of Lake Xihu near the Great Wall Station, Antarctica. Chinese Journal of Polar Research, 1997, 9(4) : 268-272(in Chinese with English abstract). [李锋, 李天杰. 南极长城 站地区西湖水化学组成影响因子分析. 极地研究, 1997, 9(4): 268-272.]

[52] Gorham E, Dean WE, Sanger JE. The chemical composition of lakes in the north-central United States. Limnology and Oceanography, 1983, 28(2): 287-301.

[53] Monica D, Fernando P, Colin R et al. Chemical composition and the nitrogen-regulated trophic state of Patagonian lakes. Limnologica-Ecology and Management of Inland Waters, 2007, 37 (1) : 17-27.

[54] Alice D. Long-term trends in major ions and nutrients in Lake Ontario. Aquatic Ecosystem Health \& Management, 2009,12 (3) : 281-295.

[55] Horne AJ, Goldman CR. Limnology. New York: McGraw-Hill, 1994. 


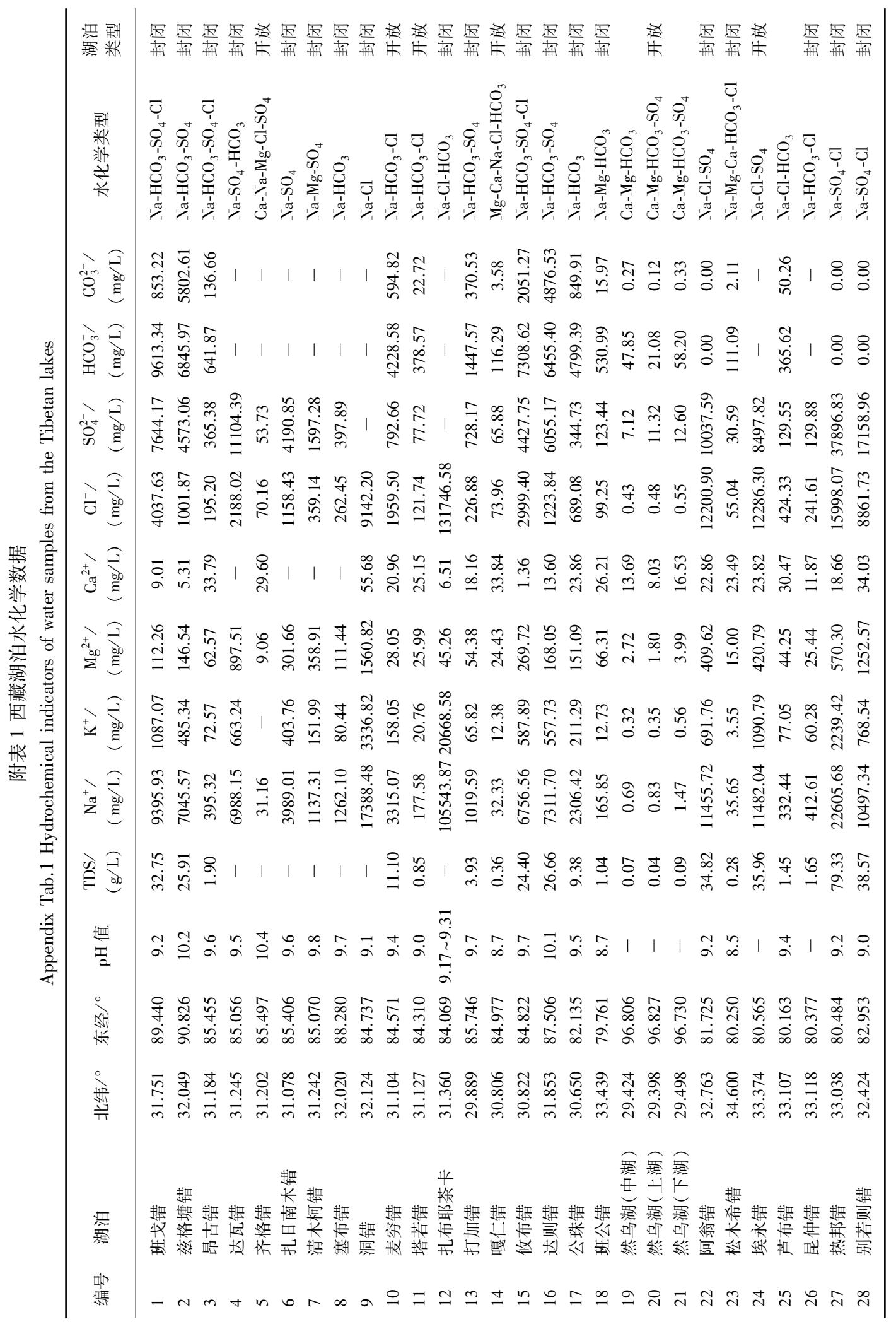




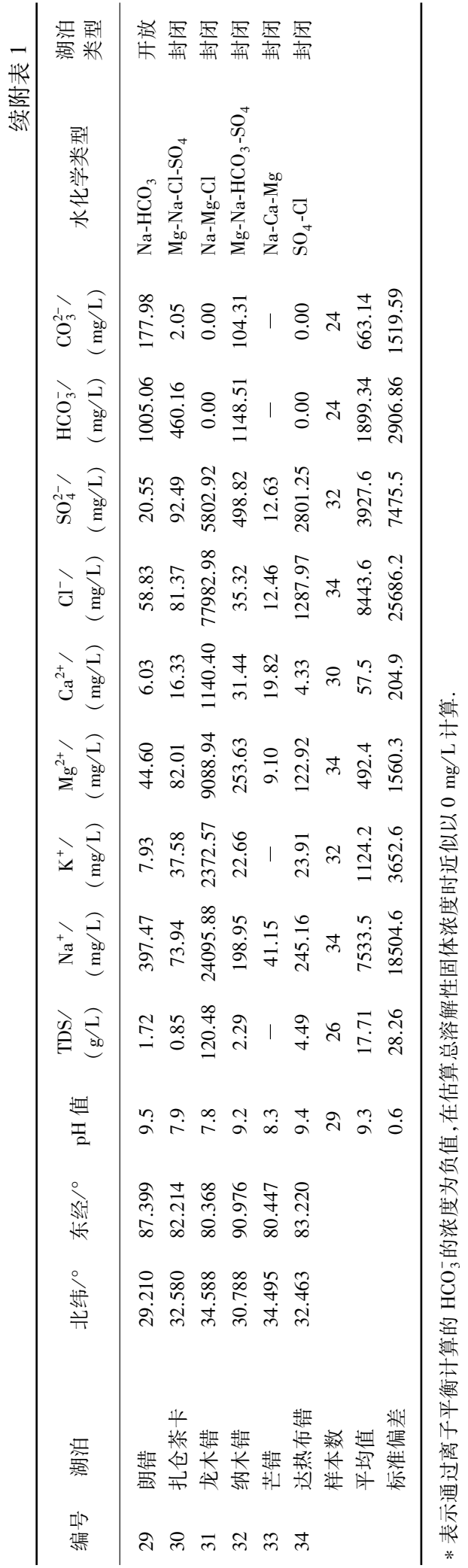

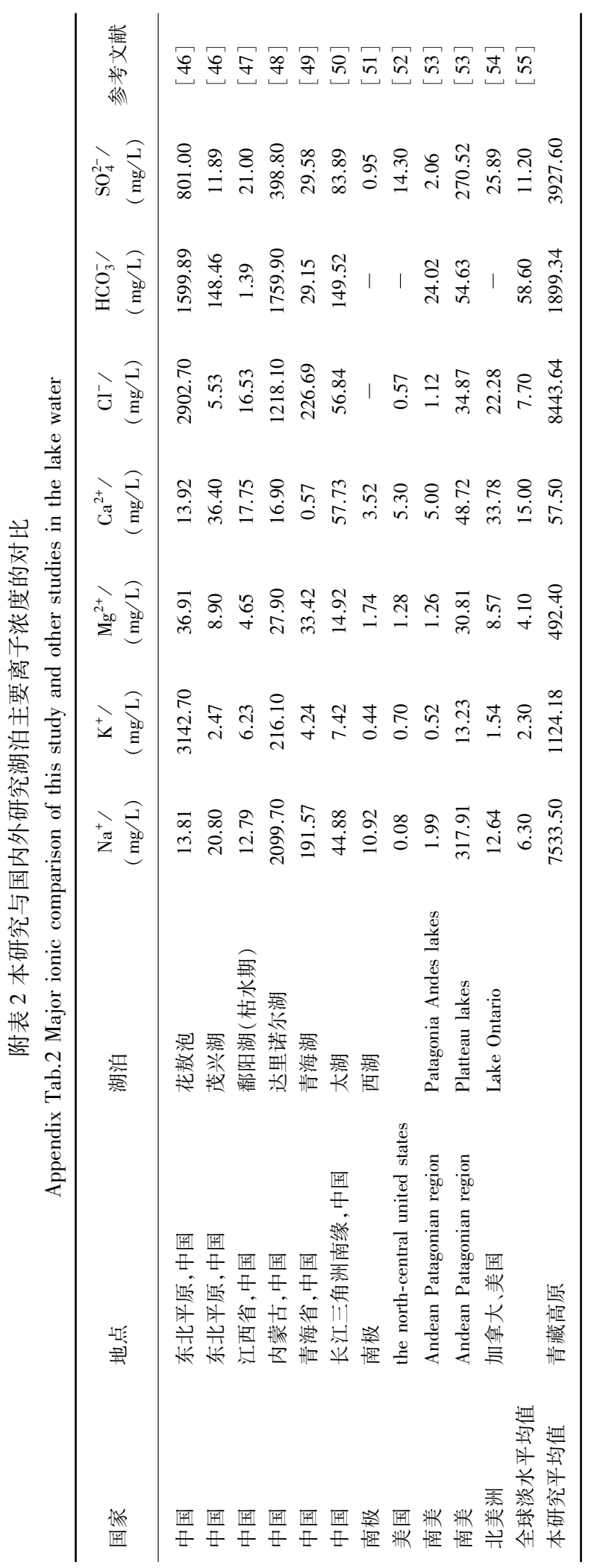

